\title{
Increased Proportions of Bacteria Capable of Cleaving IgA1 in the Pharynx of Infants with Atopic Disease
}

\author{
M. KILIAN, S. HUSBY, ${ }^{1}$ A. HøST, AND S. HALKEN ${ }^{2}$ \\ Department of Medical Microbiology and Immunology, University of Aarhus [M.K.] and Department of \\ Pediatrics, University Hospital [S.B., A.H., S.H.J, Odense, Denmark
}

\begin{abstract}
Based on the observation that children with a history of atopic disease show significantly increased levels of cleaved secretory $\operatorname{Ig} \mathrm{A}$ in nasopharyngeal secretions, we have previously formulated the hypothesis that bacteria-induced local deficiencies of the immune barrier of the upper respiratory tract may be a contributing factor in the development and perpetuation of atopic diseases. To evaluate this hypothesis, 25 infants were subjected to clinical, bacteriologic, and immunologic examination at the age of $18 \mathrm{mo}, 30 \mathrm{mo}$, and $5 \mathrm{y}$. The 11 infants, who showed clinical and immunologic evidence of atopic disease at the age of $18 \mathrm{mo}$, harbored significantly higher proportions of IgA1 protease-producing bacteria (median, 36\%; range, $14-64 \%$ ) than the 14 healthy infants (median, $5 \%$; range, $0.4-14 \%$ ). No statistically significant differences were observed at the two subsequent examinations, but healthy children showed a statistically significant increase in proportions of $\operatorname{IgAl}$ protease-producing bacteria in the pharynx with increasing age. IgA1 protease-
\end{abstract}

ABSTRACT
The mucosal membranes of the upper respiratory tract are among the most important surfaces through which sensitizing allergens pass. The principal mediator of specific humoral immunity at mucosal membranes of the body, including the upper respiratory tract, is S-IgA. Besides protecting the surfaces against infectious agents, S-IgA is capable of inhibiting the penetration of macromolecular antigens including potential allergens across mucosal membranes $(1,2)$. Clinical evidence for this function includes the demonstrated association of atopic disease with permanent or transient IgA deficiency (3-6).

S-IgA in the upper respiratory tract consists almost exclusively of the IgA1 subclass (7) which is susceptible to bacterial IgA1 proteases that specifically cleave the heavy chain of IgA1

Received April 26, 1994: accepted February 24, 1995.

Correspondence: M. Kilian, Deparıment of Medical Microbiology and Immunology, The Bartholin Building, University of Aarhus, DK-8000) Aarhus, Denmark.

Supported by grants from The Danish Medical Research Council (Grant S12-9505) and from the Danish Asthma and Allergy Foundation.

${ }^{1}$ Present address: Department of Pediatrics. Aarhus University Hospital, DK-8000 Aarhus, Denmark.

2 Present address: Department of Pediatrics, Sønderborg Hospital, DK-64010, Sønderborg, Denmark. producing bacteria detected included Streptococcus mitis biovar 1, Haemophilus influenzae, Haemophilus parahaemolyticus, Streptococcus pneumoniae, and Neisseria meningitidis, of which the first mentioned species was mainly responsible for the difference observed at the 18-mo examination. Percentage proportions of $\operatorname{IgAl}$ protease-producing bacteria were significantly related to passive smoking which may stimulate the premature and more pronounced pharyngeal colonization of the atopic infants with the $\operatorname{IgAl}$ protease-producing variant of $S$. mitis biovar 1 . The results of the study support the hypothesis that IgAl protease-producing bacteria colonizing the upper respiratory tract jeopardize the local immune barrier and, thereby, may facilitate the penetration of potential allergens resulting in atopic disease. (Pediatr Res 38: 182-186, 1995)

\section{Abbreviation}

S-IgA, secretory immunoglobulin A

in its hinge region. $\operatorname{Ig} \mathrm{A} 1$ proteases are secreted by several bacterial species that reside in the upper respiratory tract such as Haemophilus influenzae, Haemophilus parahaemolyticus, Streptococcus pneumoniae, Neisseria meningitidis, Streptococcus sanguis, Streptococcus mitis (biovar 1), and Streptococcus oralis $(8-12)$. We have previously examined the degree of IgAI protease-induced cleavage of S-IgA in nasopharyngeal secretions of a group of children. Among 97 children (age $2.6-5.7$ y) characteristic cleavage fragments of $\mathrm{S}-\operatorname{IgA} 1$, i.e. monomeric $\mathrm{Fab}$ fragments and dimeric $\mathrm{Fc}$ fragments associated with the secretory component $\left(\mathrm{Fc}_{2} \cdot \mathrm{SC}\right)$, were demonstrated at a significantly higher prevalence $(61.5 \%$ versus $11.9 \%)$ in secretions from atopic children than in healthy controls (13, 14). On this basis we presented the hypothesis that a local functional deficiency in the immune barrier of the upper respiratory tract due to extensive bacteria-induced cleavage of S-IgA1 may be a factor contributing to the development and/or perpetuation of certain atopic diseases.

This report describes a longitudinal clinical, bacteriologic, and immunologic study of a group of children from birth to 5 $y$ of age designed to evaluate this hypothesis. 


\section{METHODS}

Study population. The study included 25 infants who were part of a population study of cord blood IgE and the development of atopic disease (15). From a birth cohort of 1625 infants born at the University Hospital of Odense, Denmark, 196 infants had a cord blood IgE concentration of $\geq 0.5 \mathrm{kU} / \mathrm{L}$. These 196 infants were followed clinically together with 242 control infants with IgE levels within the normal range $(\leq 0.3$ $\mathrm{kU} / \mathrm{L}$ ). The 25 infants included in this study were the first of each of the two groups seen in the morning at the out-patient clinic at the 18-mo examination. Twelve of the infants had a family history of atopic disease (one or both parents having atopic disease) and a cord blood IgE level of $\geq 0.5 \mathrm{kU} / \mathrm{L}$. The remaining 13 infants had cord blood $\operatorname{IgE}$ levels of $\leq 0.3 \mathrm{kU} / \mathrm{L}$ and no family history of atopic disease. All 25 infants were followed for $18 \mathrm{mo}, 23$ of these for a further $12 \mathrm{mo}$, and 20 for a total of $5 \mathrm{y}$. Informed consent was obtained from parents of the infants included in the study, and the study protocol was approved by the regional Ethics Committee for Scientific Research.

Clinical examination. At the age of $18 \mathrm{mo}, 30 \mathrm{mo}$, and $5 \mathrm{y}$ the children visited the out-patient clinic. They underwent a physical examination, and a complete history was taken with emphasis on atopic disposition, diet, housing, pets, smoking habits of the parents, atopy in the family, and infections. Atopic disease was defined as one or more of the following clinical symptoms: 1) bronchial asthma; 2) atopic dermatitis (areas of scaly, erythematous, and itchy eczematous rash with atopic localization); 3) two or more episodes of urticaria of known origin; and 4) two or more episodes of gastrointestinal allergy or intolerance to specific foods with at least one, objectively verified, positive food challenge. These criteria are identical to those used by van Asperen et al. (5) and Croner et al. (16) except that, relative to the former (5), nonimmediate food reactions were included in our study.

Immunologic examination. Blood samples for IgE determination and radioallergosorbent test for several allergens were taken if the parents permitted this at the age of 18 mo and $5 \mathrm{y}$.

Bacteriologic examinations. A throat swap collected with a coal-impregnated cotton swab from the posterior oropharyngeal wall of each child was transported to the bacteriologic laboratory in modified Stuart's transport medium (Statens Seruminstitut, Copenhagen, Denmark). Within $24 \mathrm{~h}$ of collection the swab was transferred to $3 \mathrm{~mL}$ of cold brain heart infusion broth (Difco, Detroit, MI), and the sample was suspended using a Whirly mixer for $10 \mathrm{~s}$. Aliquots of $0.1 \mathrm{~mL}$ of appropriate 10 -fold dilutions in cold brain heart infusion broth were spread with a sterile bent glass rod on duplicate sets of blood agar and on heated blood (chocolate) agar plates containing $300 \mathrm{mg}$ of bacitracin/L. The inoculated agar plates were incubated for $2 \mathrm{~d}$ in an atmosphere of air plus 5\% carbon dioxide.

The total number of colony forming units in the sample was calculated on the basis of colonies counted on agar plates with from 30 to 300 colonies and taking the dilution factor into account. The relative proportion of Haemophilus species in each sample was calculated on the basis of the number of Haemophilus colonies growing on the selective chocolate agar relative to the total number of colonies growing on the nonselective blood agar taking the respective dilution factors into account.

From each of one selected blood agar and chocolate agar plate culture of each sample 50 colonies were subcultivated to purity, and each culture was examined for IgA1 protease activity by immunoelectrophoresis, using purified myeloma $\operatorname{lgA} 1$ as substrate as described previously (10). Isolates showing IgA1 protease activity were finally identified using standard techniques (17-19).

Statistical analysis. Comparison between groups was performed with nonparametrical, two-tailed Mann-Whitney $U$ test and comparisons between several groups with the Friedman test. Fischer's exact test was used for statistical evaluation of 4-fold tables, and the Spearman test was used for correlation analyses.

\section{RESULTS}

Clinical results. Of the 25 infants examined, 11 satisfied the clinical and immunologic criteria for having atopic disease at the 18-mo examination. Several of the 11 infants showed multiple clinical signs of atopy (Table 1). Among the 11 atopic infants six had shown significantly raised levels of IgE $(\geq 0.5$ $\mathrm{kU} / \mathrm{L}$ ) in cord blood. The remaining five atopic infants showed IgE levels in cord blood of $<0.1-0.1 \mathrm{kU} / \mathrm{L}$ (Table 1 ). Two of the atopic infants (subjects 4 and 5) experienced recurrent gastrointestinal and upper respiratory tract infections, respectively, in addition to signs of atopy. One of the nonallergic infants (subject 15) suffered from recurrent middle ear infections. Atopic disease at the 18 -mo examination was significantly correlated with passive smoking ( $p=0.0051$; 4-fold table).

At the 30-mo examination eight of the 23 children examined showed clinical signs of atopic disease. Two of the eight children with atopy at the 30-mo examination (subjects 20 and 24) had shown increased IgE levels in cord blood (1.3 and 1.4 $\mathrm{kU} / \mathrm{L}$ ) but revealed no clinical sign of atopic disease at the 18-mo examination. At the 5-y examination only three of the 20 children examined fulfilled the criteria for having atopic disease.

Bacteriologic findings. The total bacterial counts in the samples calculated on the basis of colonies growing on the nonselective blood agar were in the range of approximately $10^{5}$ to $5 \times 10^{6}$. The corresponding Haemophilus counts, including all Haemophilus species, calculated on the basis of growth on the selective chocolate agar, ranged from undetected (no growth from undiluted sample suspension) to $3 \times 10^{6}$. $H$. influenzae constituted from 0 to $23 \%$ (median, $<1 \%$ ) of the bacterial flora at the 18 -mo examination, from 0 to $95 \%$ (median, 1.7\%) at the 30 -mo examination, and from 0 to $63 \%$ (median, $<1 \%$ ) at the $5-y$ examination.

IgAl protease activity and atopic disease. Approximately 5500 bacterial isolates were examined for $\operatorname{IgA} 1$ protease activity. The relative proportion of the cultivable oropharyngeal bacterial flora in each subject at each of the three examinations that possessed IgA1 protease activity is shown in Table 1 . In infants $18 \mathrm{mo}$ of age without signs of atopic disease a median proportion of 5\% (range, $0.4-14.0 \%$ ) of the nasopharyngeal bacteria showed IgA1 protease activity. The proportions were significantly higher $(p<0.0005)$ in infants with atopic disease (median, 36\%; range, 14-64\%) (Fig. 1). The two children who 
Table 1. Clinical and immunologic findings and the proportion of IgA1 protease-producing bacteria in the pharynx of 25 children examined at the age of $18 \mathrm{mo}, 30 \mathrm{mo}$, and $5 \mathrm{y}$, grouped according to the presence of atopy at the first examination

\begin{tabular}{|c|c|c|c|c|c|c|c|c|c|}
\hline \multirow[b]{2}{*}{ Child } & \multirow[b]{2}{*}{$\begin{array}{l}\operatorname{IgE} \text { in cord } \\
\text { blood }^{*}\end{array}$} & \multirow[b]{2}{*}{$\begin{array}{l}\text { Passive } \\
\text { smoking }\end{array}$} & \multirow[b]{2}{*}{ Serum $\operatorname{IgE} E^{*}$} & \multicolumn{2}{|c|}{$18 \mathrm{mo}$} & \multicolumn{2}{|c|}{$30 \mathrm{mo}$} & \multicolumn{2}{|l|}{$5 y$} \\
\hline & & & & Atopic disease $\dagger$ & $\begin{array}{c}\% \\
\operatorname{IgA} 1 \mathrm{P}\end{array}$ & Atopic disease & $\begin{array}{c}\% \\
\operatorname{IgA} 1 \mathrm{P}\end{array}$ & Atopic disease & $\begin{array}{c}\% \\
\operatorname{IgA} 1 \mathrm{P}\end{array}$ \\
\hline 1 & 4.20 & + & 774.0 & CMA & 30 & Excema & 46 & None & 80 \\
\hline 2 & $<0.1$ & + & NDף & $\mathrm{U}$ & 14 & None & 20 & None & 20 \\
\hline 3 & 2.4 & + & 51.0 & $\mathrm{AD}, \mathrm{AB}, \mathrm{CMA}$ & 38 & $\mathrm{U}, \mathrm{CMA}$ & 11 & Asthma & 48 \\
\hline 4 & 0.8 & + & 1250.0 & $\mathrm{AD}, \mathrm{AB}$ & 64 & $\mathrm{AD}, \mathrm{AB}$ & 33 & $\mathrm{AD}$ & 12 \\
\hline 5 & $<0.1$ & + & 8.0 & $A D$ & 38 & None & 12 & None & 68 \\
\hline 6 & $<0.1$ & + & 6.0 & $\mathrm{AD}$ & 18 & $\mathrm{AD}$ & 2 & None & 40 \\
\hline 7 & 0.8 & + & ND & $\mathrm{AD}, \mathrm{U}$ & 52 & $\mathrm{AD}, \mathrm{U}$ & 12 & & \\
\hline 8 & 0.1 & - & 16.0 & $\mathrm{AD}$ & 31 & $\mathrm{AD}$ & 64 & None & 36 \\
\hline 9 & $<0.1$ & + & 8.0 & $A B$ & 22 & None & 10 & & \\
\hline 10 & 0.6 & + & 36.0 & $\mathrm{U}, \mathrm{AB}$ & 36 & None & 10 & $\mathrm{U}$ & 88 \\
\hline 11 & 0.6 & + & ND & $\mathrm{AB}$ & 58 & None & 2 & None & 68 \\
\hline 12 & $<0.1$ & + & 11.0 & None & 10 & & & None & 8 \\
\hline 13 & $<0.1$ & - & 6.0 & None & 2 & None & 62 & None & 60 \\
\hline 14 & $<0.1$ & - & ND & None & 0.4 & None & 23 & None & 40 \\
\hline 15 & $<0.1$ & + & 2.6 & None & 14 & None & 0 & None & 64 \\
\hline 16 & $<0.1$ & - & 9.0 & None & 0.8 & None & 6 & None & 80 \\
\hline 17 & 3.0 & - & 24.0 & None & 12 & None & 23 & None & 36 \\
\hline 18 & $<0.1$ & - & 7.0 & None & 2 & None & 98 & & \\
\hline 19 & 1.6 & - & 4.2 & None & 6 & None & 64 & & \\
\hline 20 & 1.3 & - & 30.0 & None & 4 & $\mathrm{AD}, \mathrm{AB}$ & 10 & None & 12 \\
\hline 21 & 0.8 & - & 7.0 & None & 2 & Nonc & 62 & None & 48 \\
\hline 22 & $<0.1$ & - & 2.0 & None & 10 & None & 10 & & \\
\hline 23 & 0.3 & + & 4.2 & None & 12 & & & None & 68 \\
\hline 24 & 1.4 & + & ND & None & 2 & $\mathrm{AB}$ & 32 & None & 44 \\
\hline 25 & 0.6 & - & ND & None & 14 & None & 95 & None & 100 \\
\hline
\end{tabular}

* IgE levels expressed as $\mathrm{kU} / \mathrm{L}$.

$\dagger$ Abbreviations: CMA, cows milk allergy; AD, atopic dermatitis; $\mathrm{AB}$, asthmatic bronchitis; $\mathrm{U}$, urticaria. Data are lacking for children who dropped out of this study.

$\ddagger$ IgA1 protease-producing bacteria; percentage proportion of total cultivable bacteria.

I ND, not done because of missing samples.

developed atopy between the first and second examination and had increased IgE levels in cord blood showed low levels of IgA1-producing bacteria at the 18-mo examination. At the 30-mo examination the proportion of IgA1 protease-producing bacteria in the pharyngeal flora of the eight children with atopy (median, 22\%; range, 2-64\%) was similar to those found in the 15 nonatopic children (median, 20\%; range, 0-95\%). At the 5 -y examination only three children were atopic. Consequently, no statistical analysis of the data from the 5-y examination was performed. A comparison of the figures for the healthy children at $18 \mathrm{mo}, 30 \mathrm{mo}$, and $5 \mathrm{y}$ of age revealed a statistically significant significant increase $(p=0.00166)$ in the proportion of pharyngeal bacteria that had IgA1 protease activity with increasing age. The same pattern was not observed in the atopic children who had high initial levels of IgA1 protease-producing bacteria.

Analysis of the of the $\operatorname{lgE}$ levels in cord blood and proportions of $\operatorname{IgA} 1$ protease-producing bacteria at the 18-mo examination by the Spearman test revealed no significant correlation between the two parameters.

All isolates with IgA1 protease activity were subsequently identified to species level. Table 2 summarizes the findings for the 18-mo examination. S. mitis biovar 1 constituted the majority of the bacteria with $\operatorname{IgA} 1$ protease activity. Only in three children (subjects 8, 9, and 11) with atopic disease did $H$. influenzae and $N$. meningitidis contribute significantly to the group of $\operatorname{Ig} A 1$ protease producers observed during the study. Among the 15 children who were found to be nonatopic at the 30-mo examination, five carried high levels of IgAl proteaseproducing bacteria (62-95\% of the flora), whereas the remaining showed relatively low levels (median 10\%; range $0-23 \%$ ). In three of the children with high levels, $H$. influenzae accounted for the majority of the observed protease producers (98 out of $98 \%, 95$ out of $95 \%$, and 55 out of $62 \%$ ). In contrast, in the children with low proportions of IgA1 protease-producers, S. mitis biovar 1 predominated, whereas $H$. influenzae constituted a minor part of the flora $(0-17 \%)$. Other IgA1 protease-producing species were found in insignificant numbers (data not shown).

IgA1 protease activity and passive smoking. Fifteen of the 25 infants included in the study were exposed to passive smoking in their respective homes (Table 1). There was a strong association between passive smoking and increased levels of IgA1 protease-producing bacteria in the pharyngeal microflora at the 18-mo examination $(p=0.0028)$. The median proportions of IgA1 protease-producing bacteria in the pharynx of the passive smokers and nonsmokers were $26 \%$ (range $2-64 \%$ ) and $4 \%$ (range $0.4-31 \%$ ), respectively.

\section{DISCUSSION}

The concept that development of atopic disease may be associated with $\operatorname{IgA}$ deficiency is based on three lines of 


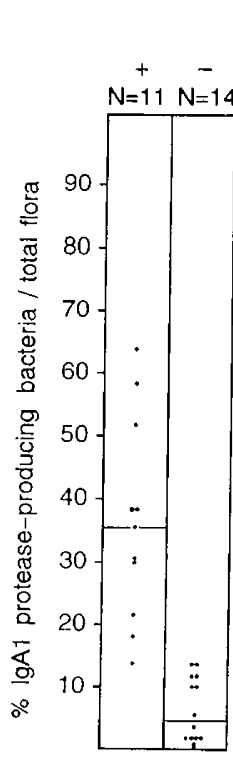

$18 \mathrm{mo}$
ATOPIC DISEASE

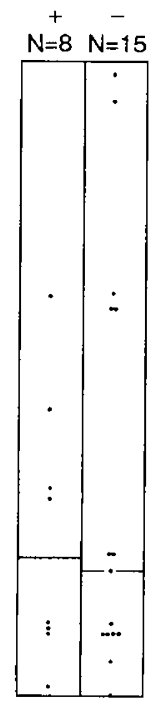

$30 \mathrm{mo}$

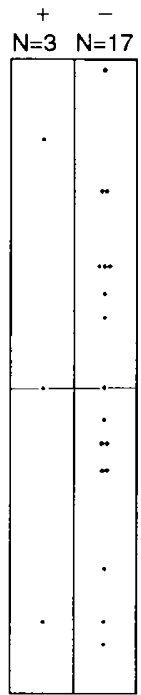

5 y
Figure 1. Percentage proportions of $\operatorname{IgA} 1$ protease-producing bacteria in the pharyngeal bacterial flora of a group of children examined at the age of $18 \mathrm{mo}$, 30 mo, and $5 \mathrm{y}$ as related to clinical and immunologic signs of atopic disease. Horizontal lines represent median values.

evidence. First, IgA deficiency results in increased penetration of intact macromolecules through mucosal membranes $(1,21)$. Second, an increased prevalence of $\operatorname{IgA}$ deficiency or reduced levels of S-IgA in nasal secretions has been observed in atopic subjects $(3,6)$, and third, comparatively low levels, yet within normal range, of serum IgA was found in atopic infants $(4,20)$. In line with these observations van Asperen et al. (5) found an increased prevalence of reduced levels or absence of salivary IgA in infants up to 20 mo of age and born to atopic parents compared with controls. Studies in older children $(5,22,23)$ and adults (24) have failed to demonstrate differences in S-IgA levels between atopic and nonatopic subjects.

Collectively, these studies suggest that the determining difference with regard to lack of or reduced IgA-mediated mucosal protection against sensitization occurs early in life. Our demonstration of significantly increased proportions of IgA1 protease-producing bacteria in the oropharynx of atopic children at the 18-mo examination compared with healthy controls, but not at later examinations, is in agreement with this notion. These bacteriologic results corroborate our previous demonstration of a significantly increased prevalence of extensive cleavage of S-IgA in nasopharyngeal secretions of atopic children resulting in virtual absence of intact, functionally competent IgA molecules and, thus, in an impaired immune barrier $(13,14)$. Although the ensuing break in the immune barrier is restricted to the upper respiratory tract, the facilitated penetration of potential allergens may conceivably result in hypersensitivity reactions at distant sites such as the gastrointestinal canal and the skin, which is in agreement with the variety of clinical signs of atopy observed in this study. However, it cannot be excluded that IgA1 proteases of bacteria swallowed from the upper respiratory tract exert a direct effect on $\operatorname{IgA} 1$ in the gastrointestinal canal.

An important question is whether the presence of $\operatorname{Ig} \mathrm{A} 1$ protease-producing bacteria and the ensuing local deficiency of functional $\mathrm{S}-\operatorname{Ig} \mathrm{A}$ is a contributing cause of the development and perpetuation of the atopic condition in the infants or merely is a secondary event. Increased occurred of Staphylococcus aureus and $\beta$-hemolytic streptococci on the skin of atopic dermatitis patients has been noted (25), and an association between development of atopy and respiratory virus infection has been suggested $(26,27)$. Theoretically, an increased prevalence of potential pathogens such as $H$. influenzae, $S$. pneumoniae, and $N$. meningitidis, which produce IgA1 protease, might reflect an increased infection susceptibility associated with but not causing the atopic condition. However, none of these potential respiratory pathogens, which produce IgA1 protease, was found at higher prevalences in the atopic children. Surprisingly, the IgA1 protease-producing species that accounted for the significant difference between the two groups was $S$. mitis biovar 1 which occurs in a proteaseproducing and a nonproducing variety $(12,19)$. Both are commensals of the oral cavity from infancy and, to a lesser extent, the oropharynx of adults $(28,29)$, and there is no reason to suspect that either is a respiratory pathogen.

Rather than reflecting a lifelong difference in the ability to become colonized by the IgA1 protease-producing variety of $S$. mitis biovar 1, our data indicate a premature predominance of this species in the pharynx of infants developing atopic disease. The reason for this unexpected finding is unknown. Passive smoking may be a contributing factor. Our data revealed a strong association between passive smoking and increased proportions of IgA1 protease-producing bacteria. Although smoking merely may be a confounding factor, it has been previously shown that tobacco smoke components may have a selective toxic effect on particular species inhabiting the respiratory tract $(30,31)$. In vitro studies have indicated that $S$. mitis and other viridans streptococci are less susceptible to the harmful effects of cigarette smoke than several Gram-negative species (32). Clinically, several studies have demonstrated an association between passive tobacco smoking and development of asthma and atopic disease (33-35).

Table 2. Proportions and identity of IgAI protease-producing bacteria in the pharynx of infants with and without signs of atopic disease at the age of $18 \mathrm{mo}$

Median $\%$ of total bacterial fora (range)

All

\begin{tabular}{lccccccc} 
Clinical status & No. & species & S. mitis & H. influenzae & N. meningitidis & H. parahaemolyticus & S. pneumoniae \\
\hline Atopy & 11 & $36(14-64)$ & $30(0-63)$ & $1(0-23)$ & $0(0-57)$ & $0(0-2)$ & 0 \\
No atopy & 14 & $5(1-14)$ & $5(0-12)$ & $<1(0-2)$ & $0(0-4)$ & $0(0-2)$ & $0(0-2)$ \\
\hline
\end{tabular}


The activity of bacterial $\operatorname{IgA} 1$ proteases are inhibitable by antibodies induced in the host. A given $H$. influenzae, pneumococcal, or meningococcal IgA1 protease may be anticipated to result in IgA cleavage only for a short period of time. Thus, clonal types of noncapsulated $H$. influenzae, which express a significant diversity of antigenic forms of IgA1 proteases, are being rapidly cleared or replaced concurrent with the development of antibodies by the host (36). The extremely high proportion of $\operatorname{IgA} 1$ producing $H$. influenzae in three nonatopic children at the 30-mo examination is likely to be a temporary situation possibly associated with an upper respiratory tract or middle ear infection. In contrast to $H$. influenzae, $S$. pneumoniae, and $N$. meningitidis IgA1 proteases $(36,37)$, enzymes produced by viridans streptococci lack antigenic variation (12) in spite of the fact that the species are found as members of the upper respiratory tract flora throughout life. Therefore, the IgA1 proteases of viridans streptococci are likely to be active only as long as neutralizing antibodies are lacking, i.e. in the first part of life. Antibodies to IgA1 proteases of viridans streptococci do not regularly develop as a result of mere colonization $(38,39)$ and may be induced primarily by crossreactive proteases released by concurrently colonizing $S$. pneumoniae $(39,40)$. Consequently, the $S$. mitis IgA1 protease conceivably contributes to impairment of the mucosal barrier mainly during the first years of life and is less relevant in older children, in whom high levels of this species were found, and also in children without atopic disease (Fig. 1). Antibodyinduced inhibition of IgA1 proteases may, thus, lead to an eventual restoration of an intact mucosal barrier and to eventual recovery from the atopic condition as indicated also by the significant reduction of the proportion of children with atopy during the 5-y observation period of this study.

Although a causal relationship has not been established, the results of this and our previous study $(13,14)$ suggest that IgAl proteases secreted by some of the bacteria colonizing the pharynx of infants induce deficiencies of the local immune barrier of the upper respiratory tract and/or increased local hyperreactivity. A premature pronounced colonization, possibly stimulated by passive smoking, of the IgA1 proteaseproducing variant of $S$. mitis appears to be particularly responsible. This bacteria-induced functional deficiency of the immune barrier may lead to allergic sensitization in otherwise predisposed infants.

\section{REFERENCES}

1. Stokes CR, Soothill JF, Turner MW 1975 Immune exclusion is a function of $\operatorname{IgA}$. Nature 255:745-746

2. Hanson LA, Brandizacg P 1989 The mucosal defence system. In: Stiehm ER (ed) Immunological Disorders in Infants and Children, 3rd Ed. WB Saunders, Philadelphia, pp $116-155$

3. Kaufmann HS, Hobbs JR 1970 Immunoglobulin deficiencies in an atopic population. Lancet 2:1061-1063

4. Taylor B, Norman AP, Orgel HA, Stokes CR, Turner MW, Soothill JF 1973 Transient IgA deficiency and pathogenesis of infantile atopy. Lancet 2:111-113

5. van Asperen PP, Glecson M, Kemp AS, Cripps AW, Geraghty SB, Mellis CM Clancy RL 1985 The relationship between atopy and salivary IgA deficiency in infancy. Clin Exp Immunol 62:753-757

6. Cortesina G, Carlcvato MT, Busse M, Baldi C, Majore L, Ruffino C 1993 Mucosal immunity in allergic rhinitis. Acta Otolaryngol (Stockh) 113:397-399

7. Kett K, Brandtzaeg P Radl J, Haaijman JJ 1987 Different subclass distribution of IgA-producing cells in human lymphoid organs and various secretory tissues. $\mathbf{J}$ Immunol 136:3611-3635
8. Plaut AG, Gilbert JV, Artenstein MS, Capra JD 1975 Neisseria gonorrhoeae and Neisseria meningitidis: Extracellular enzyme cleaves human immunoglobulin A. Science 193:1103-1105

9. Plaut AG, Genco RJ, Tomasi T 1974 Isolation of an enzyme from Streptococcus sanguis which specifically cleaves IgA. J Immunol 113:289--291

10. Kilian M, Mestecky J, Schrohenloher RE 1979 Pathogenic Haemophilus species and Streptococcus pneumoniae produce IgA protease. Infect Immun 26:143-149

11. Kilian M, Holmgren K 1981 Ecology and nature of IgA1 protease-producing streptococci in the human oral cavity and pharynx. Infect Immun 31:868-873

12. Reinholdt J, Mortensen SB, Tomana M, Kilian M. 1990 Molecular aspects of immunoglobulin A1 degradation by oral streptococci. Infect Immun 58:1186-1194

13. Sørensen CH, Kilian M 1984 Bacterium-induced cleavage of $\mathrm{IgA}$ in nasopharyngeal secretions from atopic children. Acta Pathol Microbiol Immunol Scand Sect C Immunol 92:85-87

14. Kilian M, Reinholdt J, Mortensen SB, Sørensen CH 1983 Perturbation of mucosal immune defence mechanisms by bacterial IgA proteases. Bull Eur Physiopathol Respir 19:99-104

15. Hansen LG, Høst A, Halken S, Holmskov A, Husby S, Lassen LB, Storm K, Østerballe O 1992 Cord blood lgE. II. Prediction of atopic disease. A follow-up at the age of 18 months. Allergy 47:397-403

16. Croner S, Kjellmann N-IM, Erikson B, Roth A $1982 \mathrm{IgE}$ screening in 1701 newborn infants and the development of atopic disease during infancy. Arch Dis Child $57: 364-368$

17. Kilian M 1991 Haemophilus. In: Balows A, Hausler Jr WJ, Herrmann KL, Isenberg HD, Shadomy HJ (eds) Manual of Clinical Microbiology, 5th Ed. American Society for Microbiology, Washington, DC, pp 463-470

18. Morello JA, Janda WM, Doern GV 1991 Neisseria and Branhamella. In: Balows A, Hausler Jr WJ, Herrmann KL, Isenberg HD, Shadomy HJ (eds) Manual of Clinical Microbiology, 5th Ed. American Society for Microbiology, Washington, DC, pp 258-276

19. Kilian M, Mikkelsen L, Henrichsen J. 1989 Taxonomic study of viridans streptococci: Description of Streptococcus gordonii sp. nov. and emended descriptions of Streptococcus sanguis (White and Niven 1946), Streptococcus oralis (Bridge and Sneath 1982), and Streptococcus mitis (Andrewes and Horder 1906). Int J Syst Bacteriol 39:471-484

20. Lúdviksson BR, Eriksson TH, Árdal B, Sigfússon Á, Valdimarsson H 1992 Correlation betwcen scrum immunoglobulin A concentrations and allergic manifestations in infants. J Pediatr 121:23-27

21. Cunningham-Rundles C, Brandeis WE, Good RA, Day NK 1978. Milk precipitin circulating immune complexes and IgA deficiency. Proc Natl Acad Sci USA 75:3387-3389

22. Brasher GW 1971 Salivary IgA in children with atopic disease. Ann Allergy 19:422-427

23. Salvaggio J, Lopez M, Arquembourg P, Waldman P, Sly M 1973 Salivary, nasal wash and sputum IgA concentrations in atopic and non-atopic individuals. J Allergy Clin Immunol 51:335-343

24. Sigeler DTM, Citran KM 1974 Serum and parotid salivary IgA in chronic bronchitis and asthma. Thorax 29:313-318

25. David TJ, Cambridge GC 1986 Bacterial infection and atopic eczema. Arch Dis Child 61:20-23

26. Frick OL, German DF, Mills J 1979 Development of allergy in children in association with virus infections. J Allergy Clin Immunol 63:228-234

27. Ogra PL 1989 Allergy, respiratory tract infections and bronchial hyperreactivity. Pediatr Infect Dis 8:347-352

28. Frandsen EVG, Pedrazzoli V, Kilian M 1991 Ecology of viridans streptococci in the oral cavity and pharynx. Oral Microbiol Immunol 6:129-133

29. Smith D, Anderson JM, King WF, van Houte J, Taubman MA 1993 Oral streptococcal colonization of infants. Oral Microbiol Immunol 8:1-4

30. Ertel A, Eng R, Smith SM 1991 The differential effect of cigarette smoke on the growth of bacteria found in humans. Chest 100:628-630

31. MacGregor ID 1989 Effect of smoking on oral ecology. A review of the literature. Clin Prev Dent 11:3-7

32. Bardell D 1981 Viability of six species of normal oropharyngeal bacteria after exposure to cigarette smoke in vitro. Microbios 32:7-13

33. Cogswell JJ, Mitchell EB, Alexander J 1987 Parental smoking, breast feeding, and respiratory infection in development of allergic diseases. Arch Dis Child 62:338-344

34. Andrae S, Axelson O, Björksten B, Frederiksson M, Kjellmann N-IM 1988 Symptoms of bronchial hyperreactivity and asthma in relation to environmental factors. Arch Dis Child 63:473-478

35. Halken S, Høst A, Husby S, Hansen LG, Østerballe O, Nyboe J 1991 Recurrent wheczing in relation to environmental factors in infancy. Allergy 46:507-514

36. Lomholt H, van Alphen L, Kilian M 1993 Antigenic variation of immunoglobulin A1 protcases among sequential isolates of Haemophilus infuenzae from healthy children and patients with chronic obstructive pulmonary disease. Infect Immun 61:45754581

37. Lomholt H, Poulsen K, Caugant DA, Kilian M 1992 Molecular polymorphism and epidemiology of Neisseria meningitidis immunoglobulin A1 proteases. Proc Natl Acad Sci USA 89:2120-2124

38. Gilbert J, Plaut AG, Longmaid B, Lamm ME 1983 Inhibition of microbial IgA proteases by human secretory IgA and serum. Mol Immunol 20:1039-1049

39. Reinholdt J, Kilian M 1995 Titration of inhibiting antibodies to bacterial IgAI proteases in human serum and secretions. Adv Exp Med Biol (in press)

40. Lomholt H, Kilian M 1994 Antigenic relationships among immunoglobulin A1 (IgA1) proteases from species of Haemophilus, Neisseria and Streptococcus. Infect Immun 62:3178-3183 